\title{
KEEFEKTIFAN MODEL PEMBELAJARAN PICTURE AND PICTURE DENGAN MEDIA GAMBAR SERI TERHADAP KEMAMPUAN MENULIS KARANGAN SEDERHANA
}

\author{
Nofiana Ulfa ${ }^{1}$, Zainal Arifin ${ }^{2}$, Arfilia Wijayanti ${ }^{3}$ \\ 1,2,3 Jurusan Pendidikan Guru Sekolah Dasar, FIP \\ Universitas PGRI Semarang \\ email : nofiulfa@gmail.com', zainal123@gmail.com², \\ arfilia@gmail.com ${ }^{3}$
}

\begin{abstract}
Abstrak
Penelitian ini bertujuan untuk mengetahui peningkatan kemampuan menulis siswa kelas IV SD Islam Al-Fattah Semarang. Subyek penelitian ini adalah siswa kelas IV dengan jumlah siswa 26 orang yang terdiri dari 12 orang laki-laki dan 14 orang perempuan. Metode yang digunakan dalam penelitian ini adalah observasi, dokumentasi, dan tes. Jenis penelitian ini adalah kuantitatif Penggunaan model dan media pembelajaran yang kurang variatif menyebabkan rendahnya kemampuan siswa dalam menulis karangan sederhana dilihat dari rata-rata nilai kelas IV SD Islam Al-Fattah Semarang materi menulis dalam mata pelajaran Bahasa Indonesia yaitu 63, hasil ulangan harian menulis karangan sederhana siswa dengan presentase ketuntasan 30,8\%. Sedangkan untuk KKM mata pelajaran Bahasa Indonesia kelas IV SD Islam Al-Fattah Semarang yaitu 70. Hasil penelitian keefektifan tersebut dibuktikan dengan lebih tinggi perolehan nilai rata-rata hasil posttest sebesar 76 , sedangkan rata-rata hasil pretest sebesar 56 dengan presentase kenaikan belajar siswa sebesar 16,61\%.
\end{abstract}

Kata kunci: Menulis, Picture and Picture, Gambar Seri

\begin{abstract}
This study aimed to determine the increase in writing skills of fourth grade students of Al-Fattah Islamic Elementary School Semarang. The subjects of this study were fourth grade students with 26 students consisting of 12 men and 14 women. The method used in this study was observation, documentation, and tests. This type of research is quantitative. The use of models and learning media that are less varied causes the low ability of students to write simple essays seen from the average grade IV of Al-Fattah Islamic Elementary School Semarang writing material in Indonesian language subjects, 63 , the results of essay writing simple students with completeness percentage of $30.8 \%$. Whereas for KKM fourth grade Indonesian Language subjects at Al-Fattah Islamic Elementary School Semarang that is 70 . The results of the effectiveness research were proven by the higher acquisition of the average posttest results of 76 , while the average pretest results is 56 with the percentage of student learning increases by $16.61 \%$.
\end{abstract}

Keywords: Write, Picture and Picture, Draw Series 


\section{Pendahuluan}

Pendidikan adalah proses perubahan tingkah laku, penambahan ilmu pengetahuan dan pengalaman hidup agar peserta didik menjadi lebih dewasa dalam pemikiran dan sikap. Pendidikan di era digital saat ini sangatlah pesat, kemajuan dalam bidang teknologi tidak hanya dinikmati oleh orang dewasa saja, anak-anak usia sekolah dasar juga sudah bisa menikmati dari hasil perkembangan teknologi saat ini. Teknologi banyak dimanfaatkan dalam dunia pendidikan, sebagai sarana dan prasarana interaksi antara pendidik dan peserta didik. Perkembangan teknologi saat ini mempunyai dampak positif dan damapak negatif, sebaiknya dampak positif lebih dominan dimanfaatkan oleh pengguna teknologi (Palupi, 2018).

Pendidikan merupakan sebuah sistem. Sebagai sistem, aktivitas pendidikan terbangun dalam beberapa komponen, yaitu pendidik, peserta didik, tujuan pendidikan, alat pendidikan, dan lingkungan pendidikan. Semua komponen yang membangun sistem pendidikan, saling berhubungan, saling tergantung, dan saling menentukan satu sama lain. Setiap komponen memiliki fungsi masing-masing dalam rangka mencapai tujuan pendidikan. Aktivitas pendidikan akan terselenggara dengan baik apabila didukung oleh komponen-komponen dimaksud. Fungsi pendidikan sebenarnya adalah menyediakan fasilitas yang dapat memungkinkan tugas pendidikan dapat berjalan lancar, baik secara struktural, maupun secara institusional. Secara struktural menuntut terwujudnya struktur organisasi yang mengatur jalannya proses kependidikan. Secara institusional mengandung implikasi bahwa proses kependidikan yang terjadi dalam struktur organisasi itu dilembagakan untuk lebih menjamin proses pendidikan itu berjalan secara konsisten dan berkesinambungan mengikuti kebutuhan dan perkembangan manusia yang cenderung ke arah tingkat kemampuan yang optimal (Saat, 2015).

Pasal 1 UU SISDIKNAS no. 20 tahun 2003 disebutkan bahwa Sistem Pendidikan Nasional adalah keseluruhan komponen pendidikan yang saling terkait secara terpadu untuk mencapai tujuan pendidikan nasional. Berangkat dari bunyi pasal ini dapat diketahui bahwa pendidikan adalah sistem yang merupakan suatu totalitas struktur yang terdiri dari komponen yang saling terkait dan secara bersama menuju kepada tercapainya tujuan (Soetarno, 2003: 2). Adapun komponen-komponen dalam pendidikan nasional antara lain adalah lingkungan, sarana-prasarana, sumberdaya, dan masyarakat. Komponen-komponen tersebut bekerja secara bersama-sama, saling terkait dan mendukung dalam mencapai tujuan pendidikan (Munirah, 2015).

Pendidikan dapat diperoleh baik secara formal maupun non formal. Pendidikan secara formal diperoleh dengan mengikuti program-program yang telah direncanakan, terstruktur oleh suatu institusi, departemen atau kementerian suatu negara. Sedangkan pendidikan non formal adalah pengetahuan yang diperoleh dari kehidupan sehari-hari dari berbagai pengalaman baik yang dialami atau dipelajari dari orang lain.Setiap orang berhak mendapatkan pendidikan yang layak untuk tercapainya suatu keinginan dan cita-cita yang diimpikan sejak dini. Melalui pendidikan manusia dapat memperoleh pengetahuan yang bermanfaat bagi dirinya dan orang lain.

Menurut Gagne (dalam Susanto, 2013:5) bahwa belajar dapat didefinisikan sebagai suatu proses di mana suatu organisme berubah perilakunya sebagai akibat pengalaman. Dalam penyelenggaraan pendidikan di sekolah yang melibatkan guru sebagai pendidik dan siswa sebagai peserta didik, diwujudkan dengan adanya interaksi belajar mengajar. Kegiatan berinteraksi ini membutuhkan alat, sarana atau media. Alat yang digunakan oleh manusia untuk saling berkomunikasi adalah bahasa. Mengingat pentingnya bahasa sebagai alat komunikasi, maka dalam pembelajaran bahasa tidak ditunjukkan hanya untuk mengajarkan tentang pengetahuan bahasa, tetapi lebih pada keterampilan komunikatif yang mengajarkan peserta didik untuk berbahasa secara baik dan benar, baik lisan maupun tertulis.

Menurut Fathurrohman dan Sulistyorini (2012: 9) belajar adalah proses merealisasi terhadap semua situasi yang ada di sekitar inividu. Maka dapat disimpulkan belajar merupakan proses manusia untuk mencapai berbagai macam kompetensi, keterampilan, dan 
sikap yang ditandai dengan adanya perubahan tingkah laku. Belajar dimulai sejak lahir sampai akhir hayat. Kemampuan manusia untuk belajar mempunyai karakteristik penting yang membedakan manusia dengan makhluk lainnya. Kegiatan belajar merupakan usaha manusia untuk memenuhi kebutuhannya mendapatkan ilmu atau kepandaian yang belum didapat sebelumnya. Sehingga dengan belajar manusia menjadi tahu, memahami, mengerti, dapat melaksanakan bahkan mengembangkan.

Dalam pendidikan, Bahasa Indonesia memegang peranan yang sangat penting. Bahasa Indonesia merupakan satu-satunya bahasa yang dapat digunakan untuk berkomunikasi antar suku bangsa yang berbeda adat, bahasa, maupun kebudayaan. Bahasa Indonesia memiliki peran yang sangat dalam kehidupan baik perorangan, masyarakat maupun bangsa dan negara. Pendidikan di Indonesia menempatkan bahasa Indonesia sebagai salah satu bidang studi yang diajarkan di sekolah mendapatkan pembagian waktu pembelajaran yang banyak.

Dalam pembelajaran Bahasa Indonesia ada beberapa aspek yang diperhatikan dan saling berkaitan satu dengan lainnya. Aspek-aspek tersebut adalah keterampilan mendengarkan, keterampilan menyimak, keterampilan menulis, dan keterampilan berbicara. Keempat keterampilan ini saling berinteraksi dan bersinergi untuk mewujudkan keterampilan berkomunikasi.

Salah satu keterampilan berbahasa adalah keterampilan menulis. Keterampilan menulis di sekolah dasar merupakan salah satu keterampilan yang ditekankan pembinaannya, disamping keterampilan membaca dan berhitung. Menulis merupakan proses penuangan ide atau gagasan dalam bentuk paparan bahasa tulis berupa rangkaian simbol-simbol bahasa.Menulis sebagai suatu keterampilan bahasa yang digunakan untuk berkomunikasi secara tidak langsung. Seperti yang dikatakan Dalman (2015:3) bahwa menulis merupakan suatu kegiatan berupa penyampaian pesan (informasi) secara tertulis kepada pihak lain dengan menggunakan bahasa tulis sebagai alat dan medianya.

Menulis perlu dimulai dari mengenal huruf, menyusun kata, membentuk kalimat, paragraf, sampai menulis karangan dengan baik. Menulis bukanlah kemampuan yang dapat dikuasai dengen sendirinya, melainkan harus melalui proses pembelajaran sehingga memang diperlukan sebuah proses panjang untuk menumbuhkan keinginan menulis. Pembelajaran keterampilan menulis di sekolah dasar berfungsi sebagai landasan untuk latihan keterampilan menulis di jenjang sekolah berikutnya.

Berdasarkan observasi di SD Islam AI-Fattah Semarang dapat diketahui bahwa (1) kemampuan siswa dalam menulis karangan sederhana masih kurang, (2) siswa masih belum bisa menyusun kata-kata dalam menulis karangan sederhana, (3) siswa masih belum bisa menentukan ide dalam menulis karangan sederhana, (4) penggunaan model dan media pembelajaran kurang variatif, guru hanya memberikan beberapa contoh peristiwa berdasarkan pengalaman.

Penggunaan model dan media pembelajaran yang kurang variatif menyebabkan rendahnya kemampuan siswa dalam menulis karangan sederhana dilihat dari rata-rata nilai kelas IV SD Islam Al-Fattah Semarang materi menulis dalam mata pelajaran Bahasa Indonesia yaitu 63, hasil ulangan harian menulis karangan sederhana siswa dengan persentase ketuntasan 30,8\%. Sedangkan untuk KKM mata pelajaran Bahasa Indonesia kelas IV SD Islam Al-Fattah Semarang yaitu 70. Kesalahan masih banyak ditemukan dalam menyusun kata untuk digabungkan menjadi kalimat serta penggunaan tanda baca dan ejaan. Agar siswa mau menulis perlu dipacu dengan menggunakan model dan media pembelajaran yang menarik.

Hasil studi terdahulu yang dilakukan oleh Muharipin (2015) dan mengungkapkan bahwa model pembelajaran picture and picture dapat meningkatkan kemampuan menulis siswa dengan dibuktikan persentasi keberhasilannya $26 \%$, hal tersebut juga terbukti dengan persentase hasil belajar dari $70 \%$ meningkat menjadi $100 \%$. Siswa merasa senang mengikuti pembelajaran dengan menggunakan model picture and picture, sehingga kemampuan menulis siswa meningkat dari sebelum diterapkan model picture and picture.

Berdasarkan sebab yang terjadi peneliti bermaksud untuk mengatasi permasalahan tersebut dengan menggunakan model dan media pembelajaran yang inovatif, yaitu 
menggunakan model pembelajaran picture and picture dengan media gambar seri dalam pembelajaran menulis karangan sederhana. Model ini menciptakan lingkungan belajar yang heterogen (dalam hal kemampuan akademik, jenis kelamin, maupun latar belakang sosial) sehingga dapat membuat semua siswa aktif dalam proses berfikir dan kegiatan belajar. Selain itu media gambar seri dapat mendukung siswa untuk menyusun kalimat yang digabungkan menjadi satu untuk membuat karangan sederhana berdasarkan gambar. Dilihat dari permasalahan yang ada, maka akan dilakukan penelitian kuantitatif tentang keefektifan model pembelajaran Picture and Picture dengan media gambar seri terhadap kemampuan menulis karangan sederhana siswa kelas IV SD Islam Al-Fattah Semarang.

Kata "media" berasal dari bahasa Latin "medium" yang berarti "perantara" atau "pengantar". Lebih lanjut, media merupakan sarana penyalur pesan atau informasi belajar yang hendak disampaikan oleh sumber pesan kepada sasaran atau penerima pesan tersebut. Penggunaan media pengajaran dapat membantu pencapaian keberhasilan belajar. Ditegaskan oleh Danim bahwa hasil penelitian telah banyak membuktikan efektivitas penggunaan alat bantu atau media dalam proses belajar-mengajar di kelas, terutama dalam hal peningkatan prestasi siswa. Terbatasnya media yang dipergunakan dalam kelas diduga merupakan salah satu penyebab lemahnya mutu belajar siswa.1 Dengan demikian penggunaan media dalam pengajaran di kelas merupakan sebuah kebutuhan yang tidak dapat diabaikan. Hal ini dapat dipahami mengingat proses belajar yang dialami siswa tertumpu pada berbagai kegiatan menambah ilmu dan wawasan untuk bekal hidup di masa sekarang dan masa akan datang. Salah satu upaya yang harus ditempuh adalah bagaimana menciptakan situasi belajar yang memungkinkan terjadinya proses pengalaman belajar pada diri siswa dengan menggerakkan segala sumber belajar dan cara belajar yang efektif dan efisien.2 Dalam hal ini, media pengajaran merupakan salah satu pendukung yang efektif dalam membantu terjadinya proses belajar (Mahnun, 2012).

Menurut Johnson \& Johnson (dalam Djamarah, 2006:55) model pembelajaran picture and picture adalah pembelajaran mengandalkan gambar sebagai media dalam proses pembelajaran. Gambar-gambar ini menjadi faktor utama dalam proses pembelajaran. Sehingga sebelum proses pembelajaran guru sudah menyiapkan gambar yang akan ditampilkan baik dalam bentuk kartu atau dalm bentuk cerita dalam ukuran besar. Atau jika si sekolah sudah menggunakan ICT dalam menggunakan Power Point atau softwere yang lain (Fauziah, 2014).

Model pembelajaran picture and picture adalah suatu model belajar yang menggunakan gambar dan dipasangkan/diurutkan menjadi urutan logis. Model pembelajaran ini mengandalkan gambar sebagai media dalam proses pembelajaran. Gambar-gambar ini menjadi faktor utama dalam proses pembelajaran. Sehingga sebelum proses pembelajaran guru sudah menyiapkan gambar yang akan ditampilkan baik dalam bentuk kartu atau dalam bentuk carta dalam ukuran besar.

Menurut Supriono, 2009 bahwa pembelajaran kooperatif picture and picture adalah salah satu model pembelajaran aktif yang menggunakan gambar dan dipasangkan atau diurutkan menjadi urutan yang sistematis, seperti menyusun gambar secara berurutan, menunjukkan gambar, memberi keterangan gambar dan menjelaskan gambar. picture and picture ini berbeda dengan media gambar dimana picture and picture berupa gambar yang belum disusun secara berurutan dan yang menggunakannya adalah siswa, sedangkan media gambar berupa gambar utuh yang digunakan oleh guru dalam proses pembelajaran. Dengan adanya penyusunan gambar guru dapat mengetahui kemampuan siswa dalam memahami konsep materi dan melatih berpikir logis dan sistematis, dapat melihat kemampuan siswa dalam menyusun gambar secara berurutan, menunjukkan gambar, memberi keterangan dan menjelaskan gambar, Sehingga siswa dapat menemukan konsep materi sendiri dengan membaca gambar. Adanya gambargambar yang berkaitan dengan materi belajar siswa lebih aktif dan tercapainya tujuan akhir dari proses pembelajaran yaitu hasil belajar meningkat meningkat (Ramadhani, 2017). 


\section{Metode}

Metode penelitian yang digunakan yang digunakan adalah metode penelitian kuantitatif. Metode penelitian kuantitatif adalah metode penelitian yang berdasarkan filsafat positivisme, digunakan untuk meneliti pada populasi atau sampel tertentu, teknik pengambilan sampel dilakukan secara random, pengumpulan data menggunakan instrumen penilaian, analisis data bersifat kuantitatif atau statistik dengan tujuan menguji hipotesis yang telah ditetapkan (Sugiyono, 2013). Metode penelitian yang digunakan adalah metode penelitian eksperimen. Metode penelitian eksperimen adalah metode penelitian yang digunakan untuk mencari pengaruh perlakuan tertentu terhadap yang lain dalam kondisi yang terkendalikan.

Desain penelitian yang digunakan dalam penelitian ini adalah Pre-Experimental Design, desain ini belum merupakan eksperimen sungguh-sungguh karena masih terdapat variabel luar yang ikut berpengaruh terhadap terbentuknya variabel dependen. Jadi hasil eksperimen yang merupakan variabel dependen itu bukan dipengaruhi oleh variabel independen. Hal ini terjadi karena tidak adanya variabel kontrol, dan sampel tidak dipilih secara random.

Tahap-tahap yang dilakukan dalam penelitian ini sebagai berikut:

a. Tes Awal

Sebelum pemberian perlakuan, terlebih dahulu peneliti melakukan pretest pada kelas dengan maksud untuk mengetahui keadaan siswa sebelum diberi perlakuan.

b. Pemberian perlakuan

Pada tahap ini, peneliti memberikan perlakuan pada kelas sesuai dengan perlakuan yang telah direncanakan.

c. Tes akhir

Setelah pemberian perlakuan, kemudian peneliti melakukan posttest. Pemberian posstest dilakukan untuk mengetahui seberapa besar keefektifan dari pemberian pelakuan pada kelas yang diteliti.

Penelitian ini dilaksanakan di SD Islam Al-Fattah Semarang yang terletak di Jalan Masjid Terboyo No. 111, kecamatan Gayamsari, kota Semarang. Penelitian ini dilaksanakan pada bulan November sampai April tahun 2019 pada kelas IV di SD Islam Al-Fattah Semarang tahun 2018/2019. Sampel adalah bagian dari jumlah dan karakteristik yang dimiliki oleh populasi. Sampel dalam penelitian ini adalah siswa kelas IV SD Islam Al-Fattah Semarang dengan jumlah 26 orang siswa.

Pengumpulan data adalah prosedur yang sistematik dan standar untuk mengolah data yang diperlukan. Tujuan dari pengumpulan data adalah untuk memperoleh data yang relevan, akurat dan reliabel yang berkaitan dengan penelitian. Dalam penelitian ini menggunakan beberapa teknik pengumpulan data yaitu teknik tes dan nontes. Teknik tes adalah seperangkat tugas yang harus dikerjakan oleh orang yang dites, dan berdasarkan hasil menunaikan tugas tersebut, akan dapat ditarik kesimpulan tertentu pada orang tersebut.

Dalam penelitian ini teknik tes yang digunakan untuk mengukur kemampuan menulis karangan sederhana siswa. Tes dilakukan pada awal pembelajaran (pretest) dan akhir pembelajran (posttest), hasil posttest inilah yang merupakan data hasil belajar kemampuan menulis karangan sederhana siswa. Tes yang digunakan adalah tes essay. Materi yang diajukan adalah materi pokok yang berkaitan dengan menulis karangan sederhana. Sedangkan teknik nontes berupa observasi dan dokumentasi. Observasi adalah kegiatan pengamatan, meliputi kegiatan pemusasatan perhatian terhadap suatu objek yang menggunakan seluruh alat indera yang dapat dilakukan melalui indera penglihatan, penciuman, pendengaran, perabaan dan pengecap. Dokumentasi adalah mencari data mengenai hal-hal atau variabel yang berasal dari catatan buku, surat kabar, transkip, agenda foto, dan sebagainya. Teknik ini digunakan untuk mendapatkan data sekunder. Teknik analisis data yang digunakan berupa uji normalitas awal (pretest) dan uji normalitas ahir (posttest), selain itu uji hipotesis menggunakan uji t digunakan untuk uji pembeda antara hasil nilai pretest dan posttest. 


\section{Hasil Dan Pembahasan}

Data Hasil penelitian berdasarkan nilai pretest dan posttest. Pretest sebagai data awal dari kemampuan menulis karangan sebelum diberi perlakuan, sedangkan posttest sebagai data akhir dari kemampuan menulis karangan setelah diberi perlakuan. Nilai pretest dan posttest dinyatakan tuntas apabila mencapai KKM 70.

Tabel 1. Distribusi Frekuensi Nilai Pretest

\begin{tabular}{ccc}
\hline Interval & Frekuensi & Presentase \\
\hline $30-38$ & 3 & $12 \%$ \\
$39-46$ & 6 & $23 \%$ \\
$47-54$ & 2 & $7 \%$ \\
$55-63$ & 4 & $15 \%$ \\
$64-71$ & 5 & $20 \%$ \\
$72-80$ & 6 & $23 \%$ \\
\hline Jumlah & 26 & $100 \%$ \\
\hline
\end{tabular}

Tabel 2. Ketuntasan Hasil Belajar Sebelum Diberi Perlakuan

\begin{tabular}{ccc}
\hline Nilai & Jumlah & Kriteria \\
$\leq 70$ & 19 & Tidak Tuntas \\
$\geq 70$ & 7 & Tuntas \\
Jumlah & 26 & \\
\hline
\end{tabular}

Tabel 3. Distribusi Frekuensi Nilai Posttest

\begin{tabular}{ccc}
\hline Interval & Frekuensi & Presentase \\
\hline $65-68$ & 3 & $12 \%$ \\
$69-72$ & 4 & $16 \%$ \\
$73-76$ & 7 & $26 \%$ \\
$77-80$ & 7 & $26 \%$ \\
$81-83$ & - & $0 \%$ \\
$84-87$ & 5 & $20 \%$ \\
\hline Jumlah & 26 & $100 \%$ \\
\hline
\end{tabular}

Tabel 4. Ketuntasan Hasil Belajar Sesudah Diberi Perlakuan

\begin{tabular}{ccc}
\hline Nilai & Jumlah & Kriteria \\
\hline$\leq 70$ & 3 & Tidak Tuntas \\
$\geq 70$ & 23 & Tuntas \\
\hline Jumlah & 26 & \\
\hline
\end{tabular}

Penelitian ini menggunakan uji validitas konstruk dengan menggunakan pendapat ahli yaitu dengan mengetahui tingkat kevalidan dari instrumen yang berupa silabus, rpp, soal pretes-posttest, dan soal evaluasi. Analisis validitas menggunakan Skala Likert dengan langkah-langkah: a) Memberikan skor untuk setiap item jawaban sangat baik (5), baik (4), cukup (3), kurang (2), dan sangat kurang (1), b) Menjumlahkan skor total tiap validator untuk seluruh indicator, dan c) Pemberian nilai validitas

Kategori validitas berdasarkan nilai kriteria $80 \%<x \leq 100 \%$ dapat dikatakan sangat valid, nilai $60 \%<x \leq 80 \%$ dikatakan valid, nilai $40 \%<x \leq 60 \%$ dikatakan cukup valid, nilai $20 \%<x \leq$ $40 \%$ dikatakan kurangan valid, dan nilai $0 \%<x \leq 20 \%$ dikatakan tidak valid. 
Sebelum melaksanakan uji hipotesis perlu dilakukan uji persyaratan analisis data terlebih dahulu. Uji persyaratan yang perlu dipenuhi adalah uji normalitas. Pada penelitian ini uji persyaratan terdiri atas analisis data awal dan analisis data akhir. Uji normalitas awal untuk mengetahui apakah sampel berasal dari populasi normal atau tidak. Data yang digunakan untuk uji normalitas awal adalah data berasal dari nilai pretest. Uji normalitas awal menggunakan uji liliefors yang diukur pada taraf signifikan $5 \%$ dengan ketentuan bahwa kelompok berdistribusi normal jika memenuhi kriteria $L_{o}<L_{\text {tabel }}$.

Uji normalitas awal untuk mengetahui apakah sampel berasal dari populasi normal atau tidak. Data yang digunakan untuk uji normalitas awal adalah data berasal dari nilai pretest. Uji normalitas awal menggunakan uji liliefors yang diukur pada taraf signifikan $5 \%$ dengan ketentuan bahwa kelompok berdistribusi normal jika memenuhi kriteria $\mathrm{L}_{o}<\mathrm{L}_{\text {tabel. }}$. Uji hipotesis dalam penelitian ini dihitung menggunakan uji-t yang digunakan untuk menguji apakah ada peningkatan hasil belajar siswa antara sebelum diberi perlakuan dengan sesudah diberi perlakuan berdasarkan nilai pretest dan posttest. Penelitian dengan menggunakan model picture and picture dengan media gambar seri dikatakan efektif jika data hasil sama atau lebih besar dari kriteria ketuntasan minimal (KKM) yaitu 70.

Data yang diperoleh dari hasil belajar sebelum dan sesudah diberi perlakuan dihitung dengan menggunakan Uji-t. Dengan db sebesar 25 dengan taraf signifikan $5 \%$ didapatkan $t_{\text {tabel }}$ sebesar 2,05954. Dari hasi tabel distribusi t dengan taraf signifikan $5 \%$ dan db $n-1=26-1=25$ maka didapatkan nilai $t_{\text {tabel }}=2,05954$ dan $t_{\text {hitung }}=10,59$. Jadi nilai $t_{\text {hitung }}>t_{\text {tabel, }}$ maka $H_{0}$ ditolak dan $\mathrm{H}_{\mathrm{a}}$ diterima, artinya model pembelajaran picture and picture dengan media gambar seri efektif terhadap kemampuan menulis karangan sederhana siswa kelas IV SD Islam AI-Fattah Semarang.

Penelitian ini dilaksanakan di SD Islam Al-Fattah Semarang tahun ajaran 2018/2019 pada kelas IV yang berjumlah 26 siswa. Kegiatan pembelajaran dalam penelitian ini menggunaan model pembelajaran Picture and Picture dengan media gambar seri. Diharapkan dengan menggunakan model pembelajaran Picture and Picture dengan media gambar seri memudahkan siswa untuk merangkai kata yang akan dibuat karangan sederhana berdasarkan gambar. Penelitian ini bertujuan untuk mengetahui keefektifan model pembelajaran Picture and Picture dengan media gambar seri terhadap hasil belajar pada materi menulis pengetahuan baru dengan bahasa sendiri.

Hasil pretest dan posttest diuji normalitas untuk mengetahui apakah sampel berdistribusi normal atau tidak menggunakan uji liliefors. Berdasarkan uji normalitas awal didapatkan pretest dengan $n$ sebanyak 26 siswa dan taraf signifikan $5 \%$ diperoleh nilai $L_{o}=0,1135$ dan $L_{\text {tabel }}=$ 0,1737 . Karena $L_{\circ}<L_{\text {tabel }}$ yaitu $0,1135<0,1737$ maka $H_{0}$ diterima, artinya dapat disimpulkan bahwa sampel berdistribusi normal. Hasil uji normalitas akhir dengan $\mathrm{n}$ sebanyak 26 siswa dan taraf signifikan $5 \%$ diperoleh nilai $L_{0}=0,0715$ dan $L_{\text {tabel }}=0,1737$. Karena $L_{\circ}<L_{\text {tabel }}$ yaitu 0,0715 $<0,1737$ maka $\mathrm{H}_{0}$ diterima, artinya dapat disimpulkan bahwa sampel berdistribusi normal.

Rata-rata hasil menulis karangan sederhana siswa berdasarkan hasil pretest diperoleh 56, sedangkan rata-rata hasil menulis karangan sederhana siswa berdasarkan hasil posttest diperoleh 76. Dalam prosentase pretest hanya $7,37 \%$ atau sejumlah 7 siswa yang tuntas dari 26 siswa dan 19,73\% atau 19 siswa yang tidak tuntas dari 26 siswa. Sedangkan berdasarkan hasil posttest dalam prosentase jumlah siswa yang tuntas $23,88 \%$ atau 23 siswa dari 26 siswa dan $3,12 \%$ atau 3 siswa dari 26 siswa yang tidak tuntas. Hal tersebut diperkuat dengan hasil perhitungan uji $t$ yang diperoleh $t_{\text {hitung }}=10,842$ dan $t_{\text {tabel }}=2,060$. Karena $t_{\text {hitung }} \geq t_{\text {tabel }}$ maka $H_{0}$ ditolak dan $\mathrm{H}_{\mathrm{a}}$ diterima, maka uji t hasil belajar siswa ada perbedaan yang signifikan.

Penggunaan model pembelajaran picture and picture dengan media gambar seri dapat membuat siswa lebih aktif dalam pembelajaran, menyenangkan, menarik, dan siswa dapat menulis karangan sederhana dengan baik dan benar berdasarkan gambar. Penggunaan model pembelajaran picture and picture dengan media gambar seri memudahkan siswa merangkai kalimat yang akan dibuat menjadi karangan sederhana dengan mengurutkan gambar. Pembelajaran ini efektif untuk siswa karena siswa dapat merangkai kalimat menggunakan kalimat sendiri berdasarkan urutan gambar sehingga menjadi karangan sederhana. 
Berdasarkan pengujian hipotesis penggunaan model pembelajaran picture and picture dengan media gambar seri dapat membuat siswa lebih aktif dalam pembelajaran dan siswa dapat menulis karangan sederhana dengan baik dan benar berdasarkan gambar. Penggunaan model pembelajaran picture and picture dengan media gambar seri memudahkan siswa merangkai kalimat yang akan dibuat menjadi karangan sederhana dengan mengurutkan gambar. Pembelajaran ini efektif untuk siswa karena siswa dapat merangkai kalimat menggunakan kalimat sendiri berdasarkan urutan gambar sehingga menjadi karangan sederhana. Hal tersebut dapat dilihat berdasarkan penelitian yang dilakukan di SD Islam AIFattah Semarang.

Berdasarkan uraian diatas dapat diketahui bahwa ada perbedaan yang signifikan terhadap kemampuan menulis karangan sederhana sehingga dapat disimpulkan bahwa model pembelajaran picture and picture dengan media gambar seri efektif terhadap kemampuan menulis karangan sederhana siswa kelas IV SD Islam AI-Fattah Semarang.

\section{Simpulan dan Saran}

Berdasarkan penelitian yang dilakukan di kelas IV SD Islam Al-Fattah Semarang dapat disimpulkan bahwa model pembelajaran picture and picture dengan media gambar seri efektif terhadap kemampuan menulis karangan sederhana. Hal tersebut dibuktikan dari hasil nilai sesudah diberi perlakuan lebih tinggi dibandingkan hasil nilai sebelum diberi perlakuan.

Keefektifan tersebut dibuktikan dengan lebih tinggi perolehan nilai rata-rata hasil posttest sebesar 76, sedangkan rata-rata hasil pretest sebesar 56 dengan presentase kenaikan belajar siswa sebesar 16,61\%. Berdasarkan uji hipotesis diperoleh $t_{\text {hitung }}=10,842$ dan $t_{\text {tabel }}=2,060$. Karena $t_{\text {hitung }}>t_{\text {tabel }}$ maka $\mathrm{H}_{0}$ ditolak dan $\mathrm{H}_{\mathrm{a}}$ diterima, artinya penggunaan model pembelajaran picture and picture dengan media gambar seri efektif terhadap kemampuan menulis karangan sederhana siswa kelas IV SD Islam Al-Fattah Semarang. Keefektifan dibuktikan dengan nilai ketuntasan belajar individu mencapai nilai KKM 70 dan ketuntasan pembelajaran klasikal mencapai 85\%, ketuntasan pembejalaran klasikal telah mencapai $88 \%$ artinya model pembelajaran picture and picture dengan media gambar seri efektif terhadap kemampuan menulis karangan sederhana siswa.

\section{Daftar Rujukan}

Ahmad, Abdul Karim H. 2007. Media Pembelajaran. Makassar: Badan Penerbit Universitas Negeri Makassar.

Dalman. 2015. Keterampilan Menulis. Jakarta: PT. Raja Grafindo Persada.

Fathurrohman dan Sulistyorini. 2012. Belajar dan Pembelajaran Meningkatkan Mutu Pembelajaran Sesuai Standar Nasional. Yogyakarta: Teras.

Fauziah, Tati. 2014. Penerapan Model Kooperatif Tipe Picture And Picture Pada Materi Peninggalan Sejarah Di Sekolah Dasar Negeri Banda Aceh . JURNAL PESONA DASAR Universitas Syiah Kuala Vol. 2 No.3, Oktober 2014, hal 79-87 ISSN: 23379227

Munirah. 2015. Sistem Pendidikan Di Indonesia: Antara Keinginan Dan Realita . Jurnal Auladuna, Vol. 2 No. 2 Desember 2015: 233-245

Mahnun, Nunu. 2012. Media Pembelajaran (Kajian Terhadap Langkah-Langkah Pemilihan Media Dan Implementasinya Dalam Pembelajaran) . Jurnal Pemikiran Islam; Vol. 37, No. 1 Januari-Juni 2012 
Muharipin. 2017. Peningkatan Keterampilan Menulis Karangan Narasi Melalui Media Gambar Seri Kelas III. Jurnalistrendi online vol. 2 (2). Diunduh pada 19 September 2018.

Ramadhani, Renni. 2017. Model Pembelajaran Picture And Picture Untuk Meningkatkan Hasil Belajar Siswa . Jurnal Program Studi Pendidikan Dasar Program Pascasarjana Universitas Negeri Medan e-ISSN: 2549-5976 p-ISSN: 2549-435X

Saat, Sulaiman. 2015. Faktor-Faktor Determinan Dalam Pendidikan (Studi Tentang Makna Dan Kedudukannya Dalam Pendidikan) . Jurnal Al-Ta'dib Vol. 8 No. 2, Juli-Desember 2015

Susanto, Ahmad. 2013. Teori Belajar dan Pembelajaran di Sekolah Dasar. Jakarta: Prenadamedia Group.

Sugiyono. 2014. Statistika untuk Penelitian. Bandung: Alfabeta.

Palupi, Dini. 2018. Pendidikan Karakter Pada Anak Sekolah Dasar di Era Digital . urnal Pendidikan Dasar vol. 2, no. 1, 2018 STAIN Curup - Bengkulu| p ISSN 2580-362X; e ISSN 2580-3611 